\title{
A new application technique of circular fixator for the treatment of open tibial fractures: circular fixator-hinge technique
}

\author{
Bilal Demir, M.D., Sami Sökücü, M.D., Erdem Özden, M.D., Umut Yavuz, M.D., \\ Serda Duman, Yavuz Selim Kabukçuoğlu, M.D.
}

Department of Orthopedics and Traumatology, Metin Sabancı Baltalimani Bone and Joint Disease Hospital, Istanbul

\begin{abstract}
BACKGROUND: The purpose of this study is to present and validate a hinge-fixator technique for the treatment of open tibial fractures, which has advantages in application and the follow up period.

METHODS: The technique was used in open tibia fractures of 14 adult patients. Using this method, initial anatomic reduction was achieved and temporary stability was obtained on the hinge-fixator after applications were completed. Patients' radiological and clinical results were analyzed using the Paley's criteria at the time of the last follow-up.
\end{abstract}

RESULTS: Patients were brought in for followed up analysis over a 5.4 year period. According to Paley, two patients had 'good' and I 2 patients had 'excellent' radiological results, while the functional result were excellent $(n=13)$ and good $(n=I)$, respectively.

CONCLUSION: The hinge-fixator technique is a fast and easy method that contributes to shorter operation times, reduced radiation exposure, and more comfortable treatment periods.

Key words: Circular fixator; hinge technique; tibia fracture.

\section{INTRODUCTION}

External fixators have long been used for fracture treatment. Since the introduction of the llizarov method, these fixators have gained the widespread use. Nevertheless, the basic principles of fixation techniques have not been changed, although intensive technologic developments have been recorded. ${ }^{[1-4]}$

Even though the circular fixators are not the first choice for the treatment of simple fractures, they are often preferred for complex fractures associated with soft tissue damage. [5,6] One of the greatest advantages of the circular fixators are their application to various traumatic extremities with a reduction in infection rates. ${ }^{[7,8]}$ The most important disadvan-

Address for correspondence: Bilal Demir, M.D.

67. Ada 4/II, Kardelen Sitesi, Daire.19, Ataşehir 34758 Istanbul, Turkey

Tel: +90 212 - 3237075 E-mail: bilalbirkandemir@yahoo.com

Qucik Response Code Ulus Travma Acil Cerr Derg

2013;19(6):543-547

doi: $10.5505 /$ tjtes.20I3.47936

Copyright 2013

TJTES tages of the method are patient discomfort during the follow up, patient compliance adjustments are needed, and external fixation devices are more difficult to learn compared to other methods. ${ }^{[9-11]}$

The purpose of this study is to present the circular fixator technique for the treatment of open tibial fractures. Our findings demonstrate that the circular fixator technique has major advantages in application and in the follow up period for treating open tibial fractures. Using this technique, the fragments are fixated to a simple hinge-fixator frame and the final stabilization is performed after the fracture is reduced. In addition, the duration of the operation can be shortened and the traction of the pins and wires harming the soft tissue by tension is minimized. Thus a more comfortable treatment option is facilitated.

\section{MATERIALS AND METHODS}

The method was used in open tibial fractures of 14 adult patients. Ten of the patients were male and four were female with the mean age of 41.3 years (range 24-58). Tibial fractures were located on the right side in 10 patients and on the left side in four patients. Based on the $A O$ classification system, there was one patient with type $A 2$, one $A 3$, one $B I$, five $B 2$, two $B 3$, two $\mathrm{Cl}$ and two $C 2$ fractures, respectively. 

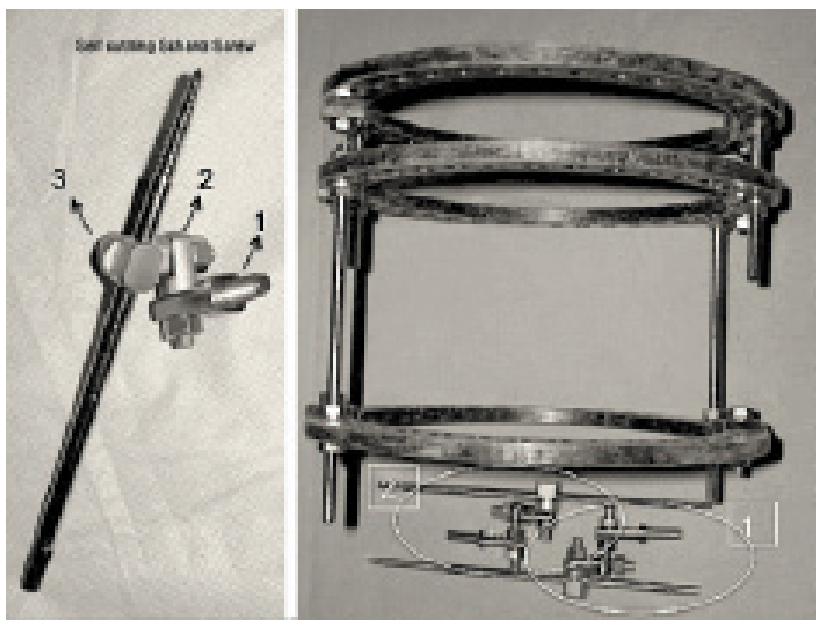

Figure 1. Hinge system was obtained by combining three offsets where each offset is perpendicular to the former one. The hinges can freely move in coronal, sagittal and transverse planes as a natural result of this binding style (The numbers 1,2,3 depicts offsets and Schanz pin in the picture). One hinge is prepared for each major fragment.

According to the Gustilo-Anderson classification, there were three cases of grade 2 fractures, three cases of grade $3 a$, six cases of grade $3 \mathrm{~b}$, and two cases of grade $3 \mathrm{~b}$. The most frequent etiologic factors for fractures were motorbike and car accidents.

Standard anterior-posterior (AP) and lateral graphics were obtained for surgical planning as well as for the follow-up. The lengths of the extremities were evaluated by comparing with the opposing tibia if the fractures were comminuted or segmented.

All patients underwent operative treatment within an average of 10.7 hours after the injury (range from five hours to seven days). All operations were performed in supine position, under fluoroscopic guidance by the same surgical team on a radiolucent operating table. 10 patients had general anesthesia whereas four had spinal block anesthesia. A tourniquet was not used in any of the patients. In two Gustilo-Anderson grade $3 b$ fracture cases, flap coverage of the skin defects were performed before the fixator application. Duration of operation, intra-operative fluoroscopy time, and number of maneuvers performed for reduction of the fractures were recorded in the operation theater. The accompanying fractures were also treated in the same session but the data were collected just for the tibial fractures. The time spent in the external fixator and time-to-weight bearing/walking were also recorded. All data were collected by reviewing the patients' medical records.

Patients' radiological and clinical results were evaluated according to the Paley's criteria at the time of last follow-up. $[12,13]$ On the plain radiographs, angles between the anatomic axis of the proximal and distal segments were evaluated,
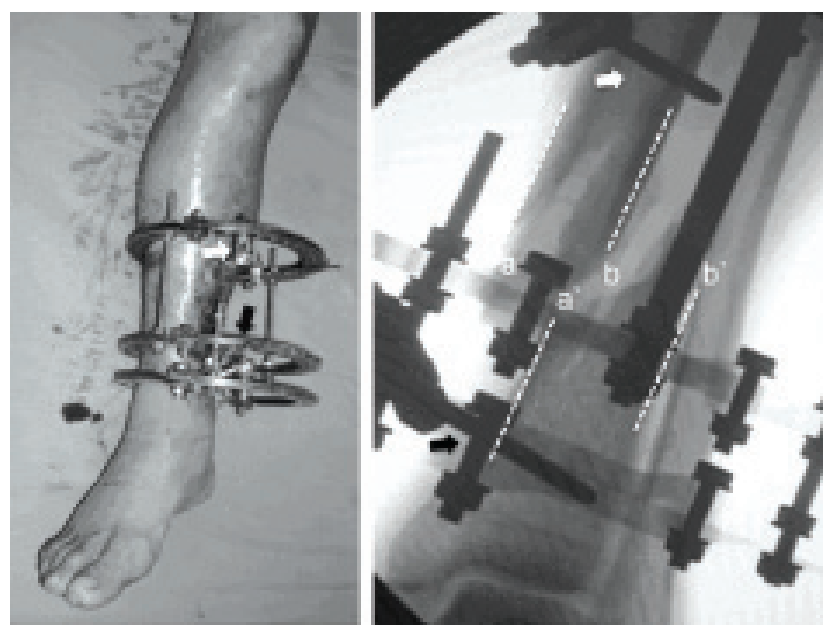

Figure 2. Fragments are fixed by Schanz pins sent through the hinges. The picture shows $a-a^{`}$ and $b-b^{`}$ as amount of fracture displacement. At this stage, reduction was still not performed.

while varus-valgus or procurvation-recurvation deformities were recorded. Complications were also recorded according to Paley's complication classification. ${ }^{[14]}$

\section{Surgical Technique}

In this hinge-fixator system, first the standard circular fixator frames were prepared. The hinge system was obtained by combining three offsets (a standard component of fixator elements), where each offset was connected perpendicular to the former one. As a result, the hinge system was able to perform free rotational movement in coronal, sagittal, and transverse planes (Figure I). Separate hinge systems were prepared and connected to the medial side of the rings for each fracture segment. These segments were fixed with Schanz screws inserted through the hinge system (Figure 2). Reduction of the fracture site was obtained by longitudinal traction. Rotation was controlled by checking the alignment of the anterior tibial crest of the distal fragment with the proximal part. After achieving anatomical reduction (which
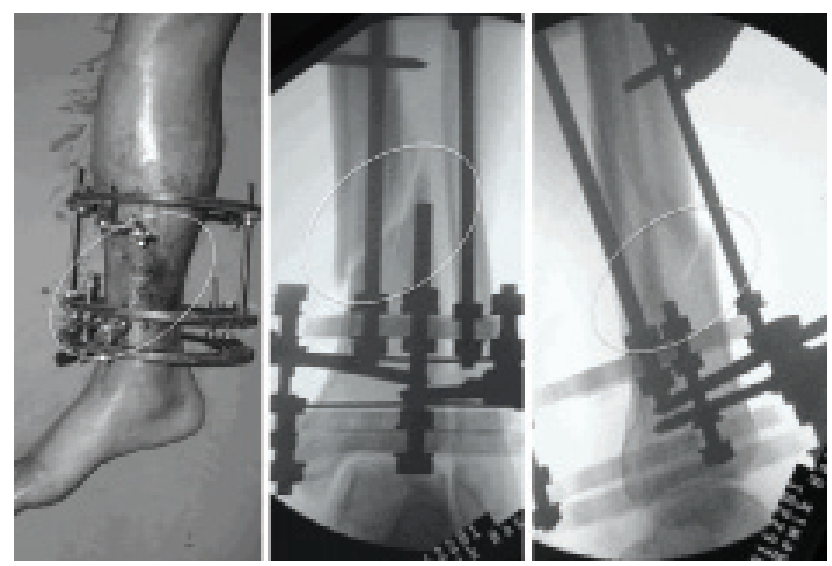

Figure 3. The photograph of leg after reduction, the fracture is fixed temporarily on the hinge-fixator. Antero posterior and lateral views showed a nearly anatomic reduction. 
was confirmed by fluoroscopy), the screws of the hinge system were tightened. Thus, the fracture was fixated in an anatomic position with the fixator frame (Figure 3). Subsequently, the stabilization was achieved by applying the wires and completing the fixator application (Figure 4).

If the fracture was segmented, a separate fixator-hinge level was used for the middle major fragment. For these types of fractures, reduction was applied for each segment, and the length of the extremity was adjusted according to the opposing tibia or according to the fibular length.

\section{RESULTS}

The mean duration of the operation was 61.14 (45-100) minutes, and the intra-operative fluoroscopy usage was 6.4 (5-12) images/patient. The average number of maneuvers performed for the reduction of the fractures was 2.7 (2-4) times. The average post-operative hospitalization period was $3.5(2-8)$ days. None of the patients required additional reduction after surgery. Time to full weight bearing walking after surgery was 2.78 days. The number of postoperative follow up visits was 3.9 (3-7) times. The mean time spent in external fixator was 5.I (4-5.8) months.

According to pin tract infection classification of Paley, 12 patients had grade I (inflammation) and five patients had grade 2 (soft tissue infection) pin tract infection. One patient had

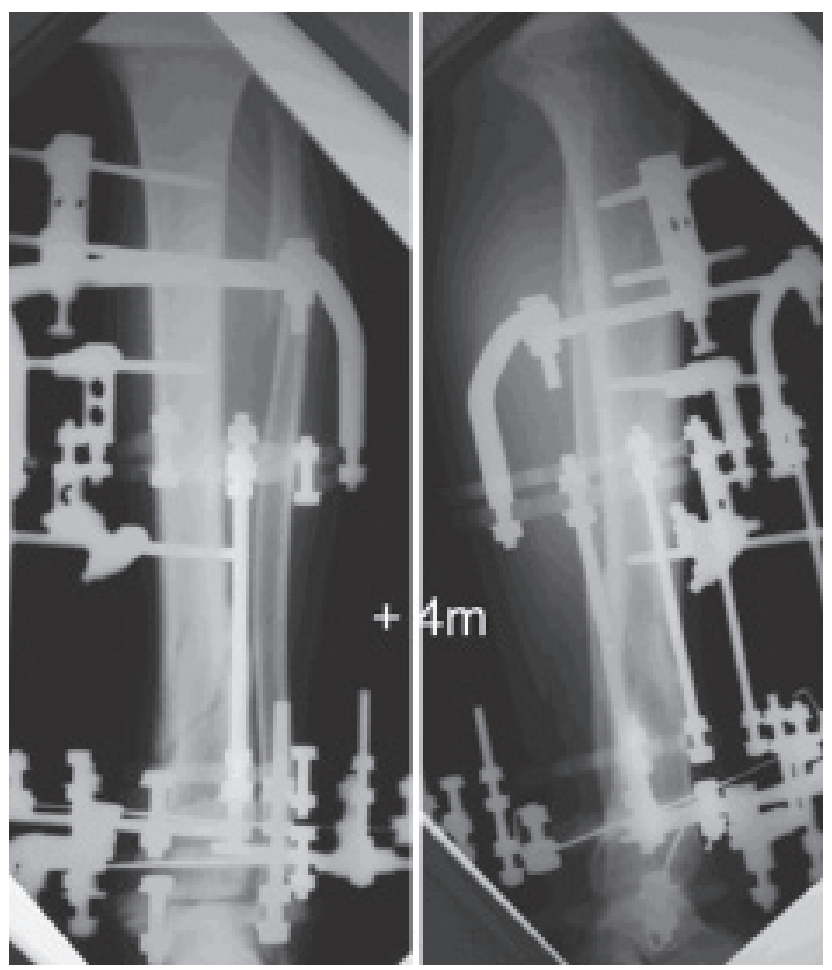

Figure 4. After reduction, the desired stabilization is obtained by completing the fixator application. Antero posterior and lateral graphics of a cruris at postoperative four months which reveals union. a wire break and fortunately did not require any additional surgery. Solid osseous union was achieved with all patients. Patients were followed up 5.4 (3-8) years. At the final visit, patients were graded according to Paley's radiologic scale.
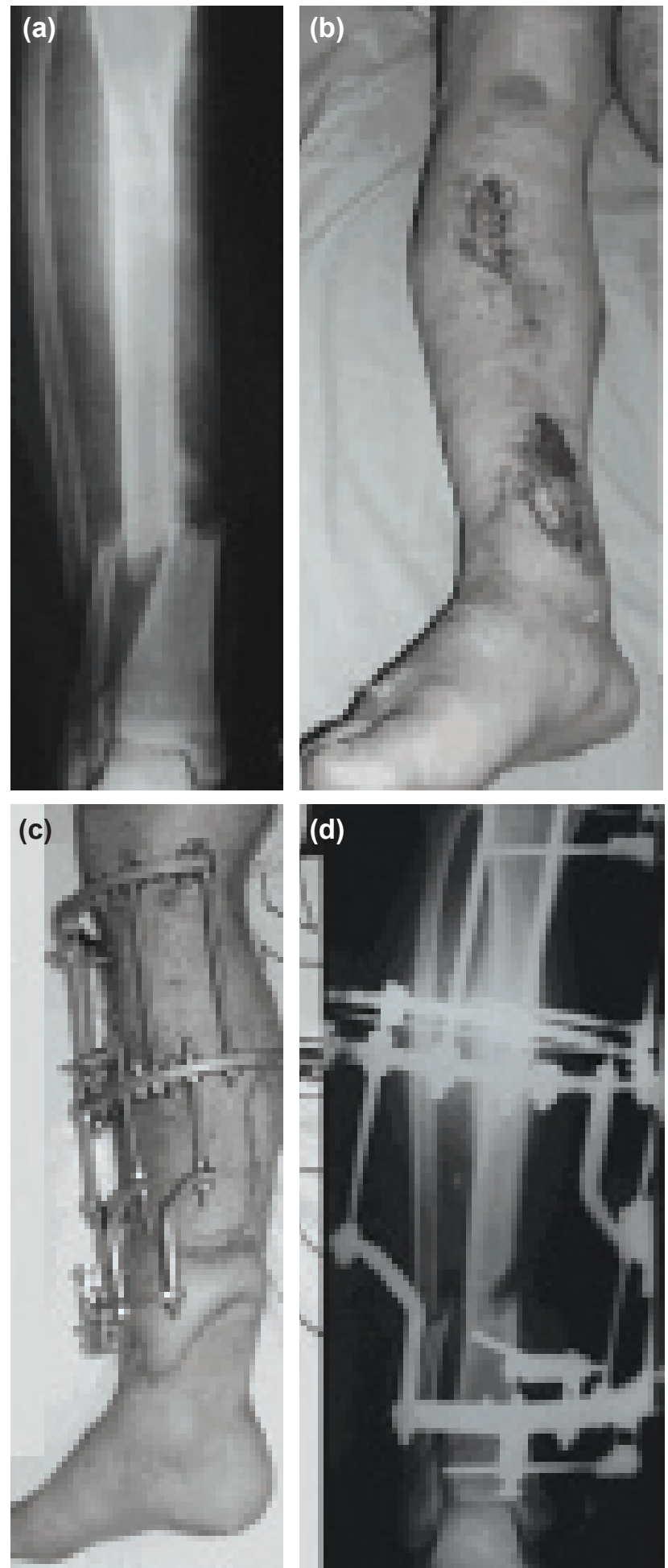

Figure 5. Fixator should be modified according to surgical procedure. (a) Radiologic anterior-posterior view, (b) pre-operative photograph of the cruris (c) a modified fixator applied and (d) follow up imaging. 
Two patients were good (one patient had 10 degrees translation deformity and one patient had 15 degrees recurvation deformity) and 12 patients were excellent. According to the clinical evaluation, I 3 patients were excellent and one patient was good ( $2 \mathrm{~cm}$ shortness). No rotational deformity was detected in any of the patients. As stated above, a single patient with segmental tibia fracture showed 10 degrees of translation deformity, while another showed 15 degrees of recurvation deformity, but no additional treatment was required in both patients.

\section{DISCUSSION}

One of the most important advantages of the hinge-fixator technique is that the reduction of the fracture is made at the initial stage. Thus, soft tissues re-locate to their original positions, and pins and wires do not lead to tractions in soft tissues. The size and weight of fixators are one of the major factors that affect patient's compliance and comfort. ${ }^{[10,14]}$ In our practice, fracture reduction is made just after inserting the first Schanz screws, and so the stabilization can be obtained by a smaller fixator. In addition, if a local or distant flap is applied for the patient's soft tissue coverage, fixator may be modified according to the condition of the leg so that it may improve patient compliance and comfort (Figure 5).

Although anatomic reduction may be obtained in the treatment of fractures by open reduction and internal fixation, there are some disadvantages of this procedure such as healing delay, infection, and soft tissue damage. ${ }^{[15-17]}$ In conservative treatment methods, some of these listed disadvantages can be eliminated, but obtaining good reduction and stable fixation still pose a problem. ${ }^{[18]}$ On the other hand, treatment of fractures with external fixators can be considered as a "semi-conservative" method between surgical treatment and conservative methods. From this point of view choosing circular external fixators in the treatment of severe open fractures may prevent many possible complications. ${ }^{[18-20]}$

There is a general consensus that better reduction result in earlier and stronger union outcomes. ${ }^{[5,17,21]}$ In conservative treatment methods, plasters or braces have limited effects on maintaining stable reduction. From this point of view, hingefixator systems may be accepted as a "sophisticated brace". In this method, reduction may be protected in a stable way, where functional use of extremity can also be possible during the treatment period. ${ }^{[1,4,7]}$

Reduction of the fracture is mainly based on applying traction and manipulation. In order to achieve a successful reduction, soft tissue contracture may not have been developed. Therefore, the affectivity of traction and manipulation is being diminished by the time passes after the fracture. ${ }^{[7,10,14]}$ In our patient group, the operations were performed within 5 hours to 7 days (average 10.7 hours) from admission to the hospital. If a patient has not undergone operation within 7 days after the initial trauma due to a concomitant disease or other additional pathologies, classic gradual reduction methods should be preferred rather than this method.

One of the most important problems encountered using the fixator during the treatment of a patient's fracture is pin-site infection. Soft tissue irritation resulting from the pushes and tractions of wires and pins frequently facilitates pin-site infections. ${ }^{[2,14,22]}$ Soft tissue healing is faster in reduced fractures and irritation around pins and wires becomes lower. Thus, as an advantage follow-up control intervals can be in longer periods. In our patient group, the average number of control visits after discharge from hospital was 3.9 (3-7)/times/patient.

In the classical application techniques, reduction is made during or after the application of fixator frames. It requires using more fixator elements which results in a larger and a heavier fixator. Furthermore, radiation exposure is higher during the reduction process. Fixator manipulations during application lead to decreases in the stability of the construct. ${ }^{[23,24]}$ In our method, fluoroscopy is used only at the reduction stage. There is no need for fluoroscopy, after reduction has been achieved. Thus, in the hinge-fixator technique radiation exposure of surgical team is also reduced. In our patient group, the mean number of fluoroscopy images is 6.4 (4-12) images.

We demonstrate that the hinge-fixator method in the treatment of tibia fractures is fast and easy with a shorter operation time, lesser radiation exposure, shorter hospital stay, longer follow up visit intervals, and a more comfortable treatment period. It also leads to excellent radiologic and clinical outcomes.

Conflicts of interest: The authors did not receive grants or outside funding in support of their research or preparation of this manuscript. They did not receive payments or other benefits or a commitment or agreement to provide such benefits from a commercial entity. No commercial entity paid or directed, or agreed to pay or direct, any benefits to any research fund, foundation, educational institution, or other charitable or nonprofit organization with which the authors are affiliated or associated.

\section{REFERENCES}

1. Al-Sayyad MJ. Taylor Spatial Frame in the treatment of pediatric and adolescent tibial shaft fractures. J Pediatr Orthop 2006;26:164-70.

2. Kai H, Yokoyama K, Shindo M, Itoman M. Problems of various fixation methods for open tibia fractures: experience in a Japanese level I trauma center. Am J Orthop (Belle Mead NJ) 1998;27:631-6.

3. Monsell FP, Howells NR, Lawniczak D, Jeffcote B, Mitchell SR. Highenergy open tibial fractures in children: treatment with a programmable circular external fixator. J Bone Joint Surg Br 2012;94:989-93. [CrossRef]

4. Zeman J, Matejka J. Use of a hybrid external fixator for treatment of tibial fractures. [Article in Czech] Acta Chir Orthop Traumatol Cech 2005;72:337-43. [Abstract]

5. Browner BD, Alberta FG, Mastella DJ. A new era in orthopedic trauma 
care. Surg Clin North Am 1999;79:1431-48. [CrossRef]

6. Müller TS, Sommer C. Minimally invasive plate osteosynthesis of the distal tibia. [Article in German] Oper Orthop Traumatol 2012;24:35467. [Abstract] [CrossRef]

7. Demir B, Gursu S, Oke R, Konya NM, Ozturk K, Sahin V. Shortening and secondary relengthening for chronically infected tibial pseudarthroses with poor soft tissues. J Orthop Sci 2009;14:525-34. [CrossRef]

8. Oztürkmen Y, Karamehmetoğlu M, Karadeniz H, Azboy I, Caniklioğlu M. Acute treatment of segmental tibial fractures with the Ilizarov method. Injury 2009;40:321-6. [CrossRef]

9. Chin TY, Bardana D, Bailey M, Williamson OD, Miller R, Edwards ER, et al. Functional outcome of tibial plateau fractures treated with the finewire fixator. Injury 2005;36:1467-75. [CrossRef]

10. Demir B, Ozturk K, Oke R, Gursu S, Aydin KB, Sahin V. A modified technique of internal bone transport. Acta Orthop Belg 2008;74:216-21.

11. Zalavras CG, Patzakis MJ, Thordarson DB, Shah S, Sherman R, Holtom $P$. Infected fractures of the distal tibial metaphysis and plafond: achievement of limb salvage with free muscle flaps, bone grafting, and ankle fusion. Clin Orthop Relat Res 2004;427:57-62. [CrossRef]

12. Paley D, Catagni MA, Argnani F, Villa A, Benedetti GB, Cattaneo R. Ilizarov treatment of tibial nonunions with bone loss. Clin Orthop Relat Res 1989;241:146-65.

13. Paley D, Maar DC. Ilizarov bone transport treatment for tibial defects. J Orthop Trauma 2000;14:76-85. [CrossRef]

14. Paley D. Problems, obstacles, and complications of limb lengthening by the Ilizarov technique. Clin Orthop Relat Res 1990;250:81-104.

15. Eralp L, Kocaoglu M, Rashid H. Reconstruction of segmental bone defects due to chronic osteomyelitis with use of an external fixator and an intramedullary nail. Surgical technique. J Bone Joint Surg Am 2007;95.

16. Howard JL, Agel J, Barei DP, Benirschke SK, Nork SE. A prospective study evaluating incision placement and wound healing for tibial plafond fractures. J Orthop Trauma 2008;22:299-306. [CrossRef]

17. Schwarz C, Wulsten D, Ellinghaus A, Lienau J, Willie BM, Duda GN. Mechanical load modulates the stimulatory effect of BMP2 in a rat nonunion model. Tissue Eng Part A 2013;19:247-54. [CrossRef]

18. Dewijze M, Pe M, Tondeur G. Sarmiento's method of conservative treatment of leg fractures. [Article in French] Acta Chir Belg 1985;85:37-41. [Abstract]

19. Fujita M, Yokoyama K, Nakamura K, Uchino M, Wakita R, Itoman M. Tibial fractures associated with crush injuries to the soft tissues of the dorsal foot in children. Injury 2004;35:272-7. [CrossRef]

20. Hall JA, Beuerlein MJ, McKee MD; Canadian Orthopaedic Trauma Society. Open reduction and internal fixation compared with circular fixator application for bicondylar tibial plateau fractures. Surgical technique. J Bone Joint Surg Am 2009;91:74-88.

21. Augat P, Simon U, Liedert A, Claes L. Mechanics and mechano-biology of fracture healing in normal and osteoporotic bone. Osteoporos Int 2005;16:S36-43. [CrossRef]

22. Saw A, Chua YP, Hossain G, Sengupta S. Rates of pin site infection during distraction osteogenesis based on monthly observations: a pilot study. J Orthop Surg (Hong Kong) 2012;20:181-4.

23. Kesemenli C, Subasi M, Necmioglu S, Kapukaya A. Treatment of multifragmentary fractures of the femur by indirect reduction (biological) and plate fixation. Injury 2002;33:691-9. [CrossRef]

24. Seide K, Weinrich N, Wenzl ME, Wolter D, Jürgens C. Three-dimensional load measurements in an external fixator. J Biomech 2004;37:1361-9.

\section{KLINIIK ÇALIŞMA - ÖZET}

\section{Açık tibia kırıklarının sirküler fiksatörler ile tedavisinde yeni bir uygulama tekniği: Fiksatör-menteşe yöntemi}

\section{Dr. Bilal Demir, Dr. Sami Sökücü, Dr. Erdem Özden, Dr. Umut Yavuz, Dr. Serda Duman, Dr. Yavuz Selim Kabukçuoğlu}

Baltalimanı Kemik ve Eklem Hastalıkları Hastanesi, Ortopedi ve Travmatoloji Kliniği, İstanbul

AMAÇ: Bu çalışmada, sirküler fiksatör-menteşe kombinasyonu ile daha kolay ve hızlı fiksatör uygulaması sağlayan, klinik ve radyolojik sonuçları geliştiren yeni bir uygulama yöntemi anlatıldı.

GEREÇ VE YÖNTEM: Önerdiğimiz uygulama yöntemi ile I 4 tibia kırığı olgusu tedavi edildi. Hastaların I0’u erkek, dördü kadın ve ortalama yaş 41 .3 (dağıım, 24-58) yıl idi. Sirküler fiksatör menteşe tekniği kullanılarak, öncelikle hızlı anatomik redüksiyon ve geçici kırık stabilizasyonu sağlandı. Skopi kontrolünden sonra fiksatör uygulaması tamamlanarak gerçek kırık stabilizasyonu yapıldı. Hastalardan elde edilen veriler ve son kontrollerde alınan klinik ve radyolojik sonuçlar Paley kriterlerine göre değerlendirildi.

BULGULAR: Tüm hastalarda solid osseoz kaynama elde edilerek, ortalama 5.4 (dağılım, 3-8) yıl boyunca takip yapıldı. Son değerlendirmede Paley'e göre radyolojik olarak 2 iyi, 12 mükemmel ve klinik olarak da 13 mükemmel, I iyi sonuç elde edildi.

TARTIŞMA: Kırıkların sirküler fiksatör-menteşe yöntemi ile tedavisinde hızı ve kolay bir uygulama imkanı sağlanmaktadır. Bu yöntemde daha kısa cerrahi süresi, daha az radyasyon maruziyeti, daha kısa hastane yatış süreleri ve daha seyrek hastene kontrolleri ile birlikte daha konforlu bir tedavi süreci sağlanmaktadır.

Anahtar sözcükler: Sirküler fiksatör; menteşe yöntemi; tibia kırı̆ıı.

Ulus Travma Acil Cerr Derg 2013;19(6):543-547 doi: 10.5505/tites.2013.47936 